\title{
The Impact of Education for Sustainable Development on Romanian Economics and Business Students' Behavior
}

\author{
Liana Badea ${ }^{1, *} \mathbb{C}^{(}$, George Laurențiu Șerban-Oprescu ${ }^{1}\left(\mathbb{D}\right.$, Silvia Dedu $^{2}(\mathbb{D})$ and \\ Grigore Ioan Piroșcă ${ }^{1}$ \\ 1 Department of Economic Doctrines and Communication, Bucharest University of Economic Studies, \\ 6 Romana Sq., District 1, 010734 Bucharest, Romania; george.serban@economie.ase.ro (G.L.Ș.-O.); \\ grigore.pirosca@economie.ase.ro (G.I.P.) \\ 2 Department of Applied Mathematics, Bucharest University of Economic Studies, 6 Romana Sq., District 1, \\ 010734 Bucharest, Romania; s_dedu@yahoo.com \\ * Correspondence: liana.badea@economie.ase.ro
}

Received: 18 August 2020; Accepted: 1 October 2020; Published: 3 October 2020

check for updates

\begin{abstract}
Education for sustainable development (ESD) has presented long-lasting interest for researchers and policy makers. Despite a significant body of research, more in depth empirical studies are required for a better understanding of how sustainable development goals are applied in higher education and how sustainable behavior could be shaped via ESD. The need for this kind of research arises from, first, the scarceness of existing studies that explore economic and business higher education, and, second, the necessity to properly assess the connection between ESD principles and students' behavior. Following this rationale, the present paper aims to provide an overview of how students' sustainable behaviors are shaped via their perception of sustainable campus initiatives, teaching staff involvement and curricula. Statistical and econometric analysis applied on data collected via a survey on students from Bucharest University of Economic Studies $(\mathrm{N}=1253)$ provides findings on the extent to which the awareness of sustainable development-specific issues acquired through education leads to sustainable behavior among students. According to the results, we argue that an increasing share of sustainable development topics combined with teaching staff involvement to raise awareness of sustainability issues are crucial to students' sustainable behavior. However, on-campus actions are unlikely to change behavior unless they are optional rather than compulsory. Our findings ratify that, since education is one of the main drivers of sustainable development, there is an urgent need for coherence in shaping higher education according to sustainability issues.
\end{abstract}

Keywords: education for sustainable development; sustainability; responsible behavior

\section{Introduction}

According to the UN Agenda 2030, sustainable development requires universality and aims for global transformation. "Universality" means that sustainable development does not only require achieving local economic, social and environmental goals, but also global challenges, such as climate change or inequality between countries. These complex issues must be dealt with by both governments and international bodies, to allow appropriate "transformative" changes in our way of living and protecting the planet [1]. Against this background, it was observed that education has a special role in all its forms, starting from primary levels to higher education. The United Nations Sustainable Development Goals (SDGs) provide an excellent opportunity to expand education for sustainable development (ESD) globally [2]. ESD is defined as a learning process or approach to teaching based 
on standards and principles that train different kinds of people to plan, cope and find solutions to problems that threaten the sustainability of our planet [3].

Hitherto, several definitions of ESD have emerged, but, at this time, there are none that are widely accepted. However, Wals considers that various approaches are paramount to ensure that ESD develops properly at the local level while including significant cultural differences [4]. Therefore, there is no need to seek consensus in defining ESD, but rather it is appropriate to assume a set of key principles covering the scope, purpose and practices of ESD [4]. Arguably, education is closely linked to all the SDGs, since no less than five of these explicitly mention the issue of education [3]. The contemporary prominence of ESD is also echoed in the growing number of academic programs for sustainability (University of Arizona, Harvard University in the USA, Lund University in Sweden, Maastricht University in the Netherlands, Leuphana University in Lüneburg in Germany, Technical University of Catalonia in Barcelona, Spain, Stellenbosch University in South Africa, University of Tokyo in Japan, etc.) [5].

On the other hand, sustainability also involves the individual, whose behavior must be adapted to meet the specific requirements of sustainability. The impact of individuals' consumption behaviors can be traced back to the growing demand for products and services such as food, water, timber, minerals and fuel. It is well known that the extensive use of resources as well as environmental damage are to blame for irreversible change of our planet. Household consumption is accountable for more than $60 \%$ of global greenhouse gas emissions and between $50 \%$ and $80 \%$ of total land, materials and water use [6]. Food and Agriculture Organization of the United Nations estimates that one third (approximately 1.5 billion tonnes of the world's food is wasted [7]. Moreover, it is estimated that the demand for water will exceed the supply by $40 \%$ in less than 15 years, as the population increases as well as the demand for resources [8].

Limiting unsustainable behavior can diminish the process of environmental damage and also support sustainable development. Consequently, since it has the ability to shape people behavior, education is paramount. It is common knowledge that the proper development of attitudes, values, responsibilities and skills needs to respect that the conception of the environment begins in childhood [9]. Geng et al. [10] revealed that adolescents and young people are more receptive, they develop sustainable behaviors more easily while they are prone to spreading sustainable behavior among others. Students should be perceived as future and current consumers, who are able to make a significant difference and to acquire and preserve good habits [11]. Moreover, they are essentially the future policymakers responsible for environmental management [12] and also the future marketing planners, decision makers, and educators of the new economy [13].

In several universities, various principles have begun to be put into practice as guidance for higher education managers to identify and apply complex solutions for future responsible management, as well as to confirm that students acquire, through education, the knowledge and skills needed to endorse sustainable development and sustainable lifestyles [14]. Managerial education, and implicitly, economic education is one of the "keys to success" for responsible leaders to work together to ensure sustainable development [14].

Although numerous international organizations and universities provide a visible commitment to encouraging sustainable development, this promptness so far has proved insufficient to change institutional and cultural practices in the case of higher education. While, at the policymaking level, the importance of ESD seems to be well-known, everyday reality shows that there is still a long way to go to achieve the assumed goals. Although there is a special place for ESD in social science research, one can easily notice that the number of studies dedicated to exploring how SDGs are applied in higher education and how the behaviors of the students are modeled by ESD is not thus far large enough since there is still lack of practice in this area [15].

Building upon these reflections, the present paper aims to provide an overview of how an economic university can multiply the effects of ESD by shaping students' sustainable behaviors and awareness via curricula, on-campus activities and teaching staff involvement in promoting sustainability topics. 
The study aims to highlight how the most representative university of economic studies in South-Eastern Europe encourages the responsible action of its students on campus and abroad through the means offered by ESD. The need for this kind of research arises from, first, the scarceness of existing studies that explore economic and business higher education, and, second, the necessity to find the most suitable methods to study this complex topic.

To deliver relevant answers to this intricate topic, our analysis is rooted in the belief that any individual's conduct is the result of his/her own perceptions, which are shaped by various aspects and circumstances. In this context, the current study features a two-step approach: first, the analysis focuses on assessing students' perceptions of their awareness of sustainable development issues acquired via university education (with a focus on curricula, teaching staff involvement and on-campus initiatives) and, second, we explore the potential connections between these perceptions and current students' behavior. The empirical analysis is based on data collected from undergraduate students from the Bucharest University of Economic Studies (BUES). This research might be a relevant case study since BUES is the most important university in Romania in terms of economic studies, ranking 801-1000 in the world in the Times Higher Education World University Ranking 2020 and first place in Romania [16]. In addition, the significant number of students enrolled in the undergraduate cycle $(27,598)$ places BUES among the largest universities with an economic and business profile in South-Eastern Europe [16].

The research results provide a novel perspective on explaining how what is happening in the university could shape current and future behaviors of students while raising awareness of sustainable development issues.

\section{Literature Review}

Higher education for sustainable development has drawn attention particularly via the Brundtland Report (1987) and the Rio Conference (1992), both of which emphasize the need to integrate sustainable development into tertiary economic education. Basically, the evolution of ESD in higher education can be traced by following six levels which address issues related to: (1) policy, administration and planning; (2) education (courses and study programs); (3) research; (4) operation of the university campus; (5) services; (6) evaluation and reporting at the institutional level [17].

According to UNESCO, ESD requires "participatory teaching and learning methods that motivate and empower students to change their behavior and take action for sustainable development" [18]. Economics researchers suggest that ESD enables students to understand the limitations of traditional business practices focused on process efficiency and profit maximization, and teaches individuals how to contribute creatively to a more sustainable world [19]. Universities can prove that the theory of sustainability and reality are closely related by reducing the impact of their own activities [20], extending their commitment to activities related to: campus management and specific operations; planning, design, construction and rehabilitation of own buildings and infrastructures; purchasing practices; mobility and involvement in community life [21]. Addressing such challenges involves critical thinking, innovative technologies and an open dialogue between science, industry and society [22].

Barros et al. highlight that, to achieve a higher level of sustainability, it is very important for the university to be concerned with the behavior of its students and teaching staff [23]. However, several elements are required to achieve the sustainability objectives and put ESD into practice. Thus, Ahmad and Ariffin show that it is not enough to merely transfer knowledge to students about sustainable behaviors, because a high level of knowledge does not certify that they will carry out this kind of behavior. In this context, what plays the most important part is the teaching staff ability to persuade and guide students towards applying knowledge in the form of actions [24]. Moh and Manaf show that students may lack the motivation to turn knowledge into practice [25]. Prestin and Pearce revealed that some students might understand that they are not able to correlate the benefits of recycling with the consequences of recycling in a sophisticated manner [26]. Ahmad et al. argued that several actions to save the environment, such as saving energy or reducing household waste can be done on the premise that anyone can do them whether they have minimal environmental knowledge 
or not [27]. In addition, various researchers and studies claim that, as individuals become more aware of environmental issues and what causes them, they will adopt more responsible behavior [28].

There are studies showing that ESD implies, by its very definition, an education based on respect for ethics and morality, because it involves both personal ethical choices and the embodiment of individual and social good [17]. Parkes et al. emphasize that not only students, but also their professors have the opportunity to influence the way of thinking and the future actions of organizations through the results of education [29]. The approach of teaching staff to sustainable development issues is decisive, since as both lecturers and researchers have the right arguments for educational institutions [30].

ESD influences not only the curricula, but also the education process and results. Sibbel suggests that traditional methods of teaching economic knowledge, centered on isolated topics and based on one-way education processes, do not provide students with the ability to solve complex problems that are specific to sustainability [31]. Therefore, it is essential to make students be more than simple consumers of knowledge and to actively engage in the community life [32]. According to Barth et al. [33], this implies a new learning culture based on participatory processes and new teaching techniques, such as different methods based on action and experiential learning approaches.

The significance of involving students as agents of change has so far been slightly overlooked [34]. Blewitt [35] emphasizes the need to shift the focus on identifying appropriate methods needed to change students' attitudes towards sustainability and their ability to recognize sustainable opportunities through teaching. Trencher et al. [36] note that there is a pressing need in universities to support precisely those topics that stimulate creativity, innovation and critical thinking in order to provide students with the ability to implement sustainable practices.

Brunstein and King revealed that, as a rule, some sustainable development actions are visible and disseminated at the level of a single department, course or discipline and they are not being deeply integrated in the curriculum in order to gain legitimacy at the university or national level [37]. These actions are also poorly correlated with the university curricula [38] and, sometimes, are traceable only at local community level [39]. Students do not always have the time and means to apply what they learn in classes [40], while the development of activities specific to sustainable development usually requires time and logistical planning [41]. When students do come to understand their involvement as an individualized activity, it becomes disconnected from the context of courses and disciplines and does not provide a coherent and collective experience that takes place inside and outside the classroom [41].

Studies have also been conducted on measuring the carbon footprint of student and teacher transport [42], the tendency to use bicycles or public transport, devices that consume less energy, the habit of turning off the lights in empty rooms etc. [43]. At the same time, importance is given to actions related to reducing water consumption [44], water treatment in universities [45] and tree planting [46]. Other approaches try to present the main barriers in incorporating sustainability-related topics into academic curricula [47].

At the university level, students should be taught to understand and find solutions to social, environmental and economic problems, to collectively implement combined actions [39]. From an educational perspective, this means involving students in the consulting activity, creating business plans, organizing events and lectures and carrying out actions by way of example [39]. It also means identifying and building strong human interactions that lead to meaningful learning to solve socio-environmental issues throughout the academic path [48]. Universities are detrimental in changing the behavior of young people [49], using, among other things, resource use competitions and sustainability programs held on campus. National competitions, such as RecycleMania and the energy conservation challenges organized by universities, aim to promote sustainable behaviors [50].

Given the magnitude of today's environmental challenges, sustainable development must include dimensions of human change, especially behavior change for sustainable development [50]. Achieving sustainable development goals requires a critical understanding of "how people make 
decisions and act on themselves, how they think, influence and relate to each other, and how they develop beliefs and attitudes" [51]. Kalamas Hedden et al. [52] and Shephard [53] demonstrated that active learning is suitable for ESD because it involves real-world problems that require practical solutions and hands-on experience. Experiences in everyday life and facilitating social learning by incorporating stakeholder participation can help improve responsible environmental and societal behavior [54]. In order to understand the complexity and multidisciplinary nature of sustainability issues [55], students must live the experience and this is possible only by incorporating pedagogical tools that bring them closer to reality. In this regard, researchers have recommended social constructive pedagogy [56], experiential learning [54], field-based travel courses, outdoor adventure trips for learning and others [57].

The literature review pinpoints that the topic is of interest not only among scholars and causes a significant series of debates as there is still no general consensus. Moreover, this topic generates extensive studies, especially in the case of the attitude and behavior of students with an economic and business profile towards the application of ESD principles.

\section{Materials and Methods}

According to literature review, although the issue of ESD has been extensively analyzed, the link between students' perception of how they became acquainted during university years with the issue of sustainability and their behavior in everyday life requires thorough exploration. In this context, this study aims to assess the influence of ESD on present and future behaviors of students. To accomplish this aim, the research measures, in the first phase, students' perceptions on how university education has managed to focus their attention on sustainable development and, in the second phase, students' views on their recent sustainable development-oriented behavior. Thus, the main research question to which this study seeks to provide an answer is: "To what extent is the awareness of sustainable development-specific issues acquired through education leading to a sustainable behavior among students?".

Starting in 2018, the National Strategy for Sustainable Development of Romania 2030 creates the framework for 17 sustainable development goals, which are based on three main pillars: economic, social and environmental. According to this strategy, "higher education holds autonomy and public responsibility expressed in the university charta, equity and university ethics policies defined in the Code of Ethics and Professional Ethics" [58]. Previous empirical studies reveal that ESD among economics students in Romania is at an early stage; however, economic and business universities tend to more effectively develop ESD. In this context, our empirical analysis focuses on one of these universities. We consider this research to be relevant for a better understanding of this topic since the selected organization (BUES) is one the most representative universities of economic and business studies in terms of size (over 25,000 students and 12 faculties) and ranking. Moreover, in recent years, BUES made significant investments to comply with current trends in sustainable development such as selective recycling, water and energy saving, paper consumption reduction and a more flexible and efficient organization. In a preceding study conducted in the same university, Piroșcă et al. [16] examined students' perception of how recent curricula addresses general and specific concepts related to sustainable development. According to this research [16], BUES curricula deal with various aspects specific to sustainable development (sustainable growth, sustainable production, resource efficiency, circular economy, poverty, green economy, justice and cohesion, equity, diversity, human rights, global warming, greenhouse effect, resource conservation, biodiversity, pollution, etc.). Nevertheless, teaching modules explicitly addressing sustainable developments issues, are yet to be introduced at BUES. Piroșcă et al. claim that 3rd year students report a higher level of knowledge on sustainable development than 1st year students, while subjects' perceptions of the level of knowledge acquired on sustainable development topics are overall "below average" [16]. As anticipated, subjects reported a higher perceived knowledge level in reference to economic dimensions of sustainable development [16]. Additionally, another study conducted on BUES indicates that, within the university, 
there are a significant number of research projects that focus on sustainable development while symposiums, conferences, and summers schools on this topic are frequently held in campus [59]. However, these studies are mainly focused on inputs (sustainable development initiatives and how these are perceived by students), whereas our analysis takes a step further by exploring the potential outcomes (specific students' actions and behavior).

As an instrument for data collection, we used a survey that, via 12 items measured on a 5-point Likert scale (1-“Not at all" to 5-“To a very large extent"), assesses students' opinions on acquired ESD and actions taken as a result. The questionnaire was completed by 1253 students randomly selected from Bucharest University of Economic Studies between 11 November and 5 December 2019, in paper and pencil, in the presence of one of the investigators. Since total population size is 27,598 , using Cochran's formula, the sample size provides an acceptable margin of error $(3 \%, p<0.05)$. The sample is evenly balanced as it features the following structure: $41.42 \%$ students in the 1 st year of study (population size $=11,153$ ), $30.73 \%$ students in the 2 nd year (population size $=8197$ ) and $27.85 \%$ students in 3rd year (population size $=8194$ ). Participation in the survey was voluntary, and respondents were informed that the data provided would be used in a study analyzing students' views on ESD. Given the exploratory nature of this research, we consider that the sample is representative enough to allow the analysis of trends related to the opinions and behavior of Romanian economics and business students.

In line with previously mentioned studies and current ongoing campus initiatives at BUES, our study uses the following metrics to assess students' awareness of university efforts to promote ESD: (1) on-campus activities dedicated to sustainable development; (2) teaching staff involvement in promoting sustainable development topics and (3) the degree of coverage in the university curricula of sustainable development issues. These were considered independent input variables in our analysis. The descriptive statistics of the collected data corresponding to the three variables are presented in Table 1.

Table 1. Descriptive statistics of education for sustainable development (ESD) variables.

\begin{tabular}{ccccccccc}
\hline Variable & Obs. & Min & Max & Media & SD & VAR & Skewness & Kurtosis \\
\hline On-campus actions for sustainable development $\left(v_{1}\right)$ & 1253 & 1 & 5 & 2.53 & 1.08 & 1.17 & 0.14 & -0.81 \\
Teaching staff involvement $\left(v_{2}\right)$ & 1253 & 1 & 5 & 2.47 & 1.17 & 1.38 & 0.28 & -0.89 \\
Curricula $\left(v_{3}\right)$ & 1253 & 1 & 5 & 2.20 & 1.05 & 1.11 & 0.36 & -0.83 \\
\hline
\end{tabular}

Source: authors' calculations.

On the other hand, students' opinions on how their behavior complied with specific goals of sustainable development were measured through 9 variables: (1) electricity savings to protect resources and the environment; (2) paper/glass recycling; (3) selective waste collection; (4) the purchase of eco-friendly or fair trade products; (5) volunteering in the community; (6) donations to social causes; (7) avoidance of environmentally harmful packaging; (8) use of energy saving light bulbs; (9) avoidance of excessive food purchases. The descriptive statistics of the corresponding collected data are presented in Table 2.

Table 2. Descriptive statistics of behavioral variables.

\begin{tabular}{|c|c|c|c|c|c|c|c|c|}
\hline Variable & Obs. & Min & Max & Media & SD & VAR & Skewness & Kurtosis \\
\hline Paper/glass recycling $\left(b_{2}\right)$ & 1253 & 1 & 5 & 3.24 & 1.20 & 1.44 & -0.23 & -0.74 \\
\hline Purchase of eco-friendly or fair trade products $\left(b_{4}\right)$ & 1253 & 1 & 5 & 2.82 & 1.18 & 1.39 & 0.08 & -0.83 \\
\hline Volunteering in the community $\left(b_{5}\right)$ & 1253 & 1 & 5 & 2.34 & 1.32 & 1.74 & 0.58 & -0.83 \\
\hline Donations to social causes $\left(b_{6}\right)$ & 1253 & 1 & 5 & 2.79 & 1.29 & 1.66 & 0.05 & -1.10 \\
\hline Avoiding excessive food purchases $\left(b_{9}\right)$ & 1253 & 1 & 5 & 3.79 & 1.21 & 1.48 & -0.78 & -0.39 \\
\hline
\end{tabular}

Source: authors' calculations. 
Given the relatively large number of variables that describe students' behavior, exploratory factor analysis was applied to condense these variables and, thus, to identify the main trends in the sustainable behavior of students. The Kaiser-Meyer-Olkin (KMO) value in the case of the 9 variables was 0.836 , that was higher than the standard value (0.800). As a result of performing the Bartlett sphericity test, a Chi-square value of 3006.949 was obtained with 36 degrees of freedom at a significance level of 0.00. All these values indicate that the data are suitable for a factor analysis. Following the factor analysis, 9 factors were obtained whose eigenvalues and cumulative probability are presented in Table 3. According to Table 3, there are three main factors which have an eigenvalue greater than or close to 1 and that cumulatively explain approximately $64 \%$ of the total variation of the data.

Table 3. Factors resulting from exploratory analysis.

\begin{tabular}{cccccccccc}
\hline Factor & F1 & F2 & F3 & F4 & F5 & F6 & F7 & F8 & F9 \\
\hline Eigenvalue & 3.625 & 1.193 & 0.923 & 0.718 & 0.626 & 0.552 & 0.518 & 0.480 & 0.365 \\
Variability (\%) & 40.274 & 13.256 & 10.254 & 7.982 & 6.956 & 6.132 & 5.759 & 5.333 & 4.053 \\
Cumulative (\%) & 40.274 & 53.530 & 63.784 & 71.766 & 78.722 & 84.855 & 90.614 & 95.947 & 100.000 \\
\hline \multicolumn{8}{c}{ Source: authors' calculations }
\end{tabular}

The percentage contribution of the variables to the three factors is presented in Table 4.

Table 4. Contribution of variables to factors (\%).

\begin{tabular}{cccc}
\hline Variables & F1 & F2 & F3 \\
\hline Electricity savings $\left(b_{1}\right)$ & 8.477 & 11.066 & 0.055 \\
Paper/glass recycling $\left(b_{2}\right)$ & 12.863 & 2.048 & 31.497 \\
Selective waste collection $\left(b_{3}\right)$ & 12.805 & 4.833 & 30.459 \\
Purchase of eco-friendly or fair trade products $\left(b_{4}\right)$ & 13.781 & 0.075 & 0.002 \\
Volunteering in the community $\left(b_{5}\right)$ & 8.715 & 25.961 & 12.809 \\
Donations for social causes $\left(b_{6}\right)$ & 9.229 & 20.807 & 16.916 \\
Avoiding environmentally harmful packaging $\left(b_{7}\right)$ & 12.931 & 4.606 & 1.379 \\
Use of energy saving light bulbs $\left(b_{8}\right)$ & 12.859 & 6.905 & 3.972 \\
Avoiding excessive food purchases $\left(b_{9}\right)$ & 8.339 & 23.698 & 2.910 \\
\hline
\end{tabular}

Source: authors' calculations.

According to Table 4, it can be easily seen that the first factor (F1) is mainly formed from the variables describing the behaviors aimed at environmental protection (electricity saving and the use of energy-saving light bulbs to protect the environment, avoidance of environmentally harmful packaging), therefore, in the analysis, this factor has been designated as Environmental Protection Actions. The second factor results mainly from the contribution of the variables describing the involvement of students in community life to ensure the sustainable development of the community (volunteering, donations for social causes, and avoidance of excessive food purchase) and designates the behavior towards Actions of Involvement in Community Life. The third factor results from the major contribution of the variables that describe the activities of recycling and selective waste collection, and is called Selective Recycling/Collection Actions. These three main components are integer values computed from linear combinations of variables constructed using the following equations:

$$
\begin{gathered}
F 1=0.085 b_{1}+0.129 b_{2}+0.128 b_{3}+0.137 b_{4}+0.087 b_{5}+0.092 b_{6}+0.129 b_{7}+0.129 b_{8}+0.083 b_{9} \\
F 2=0.111 b_{1}+0.020 b_{2}+0.048 b_{3}+0.001 b_{4}+0.260 b_{5}+0.208 b_{6}+0.0460 b_{7}+0.069 b_{8}+0.237 b_{9} \\
F 3=0.001 b_{1}+0.315 b_{2}+0.305 b_{3}+0.128 b_{5}+0.169 b_{6}+0.014 b_{7}+0.040 b+0.029 b_{9}
\end{gathered}
$$

The descriptive statistics of the integer values of the behavior factors extracted from factor analysis are presented in Table 5. 
Table 5. Summary statistics of output variables.

\begin{tabular}{ccccccc}
\hline Variable & Obs. & Min & Max & Mean & Std Deviation & Variance \\
\hline Environmental Protection Actions (F1) & 1253 & 1 & 5 & 2.597 & 0.914 & 0.835 \\
Actions of Involvement in Community Life (F2) & 1253 & 1 & 5 & 2.218 & 1.027 & 1.056 \\
Selective Recycling/Collection Actions (F3) & 1253 & 1 & 5 & 2.583 & 0.977 & 0.956 \\
\hline
\end{tabular}

Source: authors' calculations.

According to research question, the study focused on analyzing the influences of input variables on the three factors extracted from behavior variables. In this context, a Multinomial Logistic Regression (MLR) has been performed in order to model the effect of the three independent variables $\left(v_{1}\right.$-on-campus sustainable development activities; $v_{2}$ 一teaching staff willingness to promote sustainable development topics and $v_{3}$-the degree of coverage in the university curricula of sustainable development issues) on the response variables, represented by the three principal components (F1-Environmental Protection Actions; F2-Actions of Involvement in Community Life and F3 Selective Recycling/Collection Actions). MLR represents an effective tool for analyzing discrete datasets with several response categories. In our case, it aims at modeling and further predicting the response variables based on the known values of the independent variables, regarded as determinants of the education for sustainable development.

To provide an accurate and efficient data analysis, we designed three MLR models that focus on three distinct cases: (1) the impact of input variables on predicting Environmental Protection Actions (MLR-F1); (2) the impact of input variables on predicting Actions of Involvement in Community Life (MLR-F2) and (3) the impact of input variables on predicting Selective Recycling/Collection Actions (MLR-F3).

Tables 6 and 7 provide the values of several indicators regarding the goodness of fit of the models.

Table 6. Goodness-of-fit statistics.

\begin{tabular}{ccccccc}
\hline \multirow{2}{*}{ Statistic } & \multicolumn{2}{c}{ MLR-F1 } & \multicolumn{2}{c}{ MLR-F2 } & \multicolumn{2}{c}{ MLR-F3 } \\
\cline { 2 - 7 } & Independent & Full & Independent & Full & Independent & Full \\
\hline Observations & 627 & 627 & 627 & 627 & 627 & 627 \\
Sum of weights & 627.000 & 627.000 & 627.000 & 627.000 & 627.000 & 627.000 \\
Degrees of freedom & 626 & 611 & 626 & 611 & 626 & 611 \\
-2 Log(Likelihood) & 2953.564 & 1969.319 & 2468.542 & 1916.165 & 2468.336 & 1944.306 \\
R $^{2}$ (Cox and Snell) & 0.000 & 0.241 & 0.000 & 0.224 & 0.000 & 0.212 \\
R $^{2}$ (Nagelkerke) & 0.000 & 0.631 & 0.000 & 0.586 & 0.000 & 0.566 \\
AIC & 0.000 & 0.641 & 0.000 & 0.597 & 0.000 & 0.578 \\
SBC & 2619.328 & 2072.374 & 2476.542 & 1948.165 & 2476.336 & 1976.306 \\
Iterations & 0 & 18 & 0 & 14 & 0 & 18 \\
\hline
\end{tabular}

Table 7. Test of the null hypothesis.

\begin{tabular}{cccccccc}
\hline Hypothesis & \multicolumn{9}{c}{ MLR-F1H0: Y = 0.196 } & \multicolumn{2}{c}{ MLR-F2H0: Y = 0.295 } & \multicolumn{2}{c}{ MLR-F3H0: Y = 0.244 } \\
\hline Statistic & DF & Chi2 & Pr > Chi2 & Chi2 & Pr $>$ Chi2 & Chi2 & Pr $>$ Chi2 \\
\hline-2 Log(Likelihood) & 12 & 624.245 & $<0.0001$ & 552.376 & $<0.0001$ & 524.030 & $<0.0001$ \\
Score & 12 & 1445.259 & $<0.0001$ & 1406.237 & $<0.0001$ & 1301.573 & $<0.0001$ \\
Wald & 12 & 44.980 & $<0.0001$ & 83.779 & $<0.0001$ & 65.289 & $<0.0001$ \\
\hline \multicolumn{7}{c}{ Source: authors' calculations. }
\end{tabular}

As shown in Table 7, the probability corresponding to the Chi-square test on the log ratio is lower than 0.0001 , thus significant information is generated by the variables considered in all three cases.

The empirical results and discussions on this topic are further detailed in the next section. 


\section{Results and Discussion}

Following the initial research question and the methodology specific to multinomial logistic regression, the study results were focused on the following question: "What are the odds that a marginal change in perceived ESD could shift students' behavior from the lower to the upper bound of the scale?". Applying three distinct MLR models we explore the extent to which changes in students' perceptions of campus activities, university staff involvement and curricula could alter their sustainable development behavior. More specifically, we investigate if students are more likely to adopt a "Total agreement" behavior rather than a "Total disagreement" one, regarding Environmental Protection Actions (MLR-F1), Actions of Involvement in Community Life (MLR-F2) and Selective Recycling/Collection Actions (MLR-F3). The parameters for "Total agreement" status for all three models are displayed in Table 8. Odds ratios corresponding to a 0.95 probability level are also displayed for a better understanding of the results.

Table 8. Parameters for "Total agreement" status.

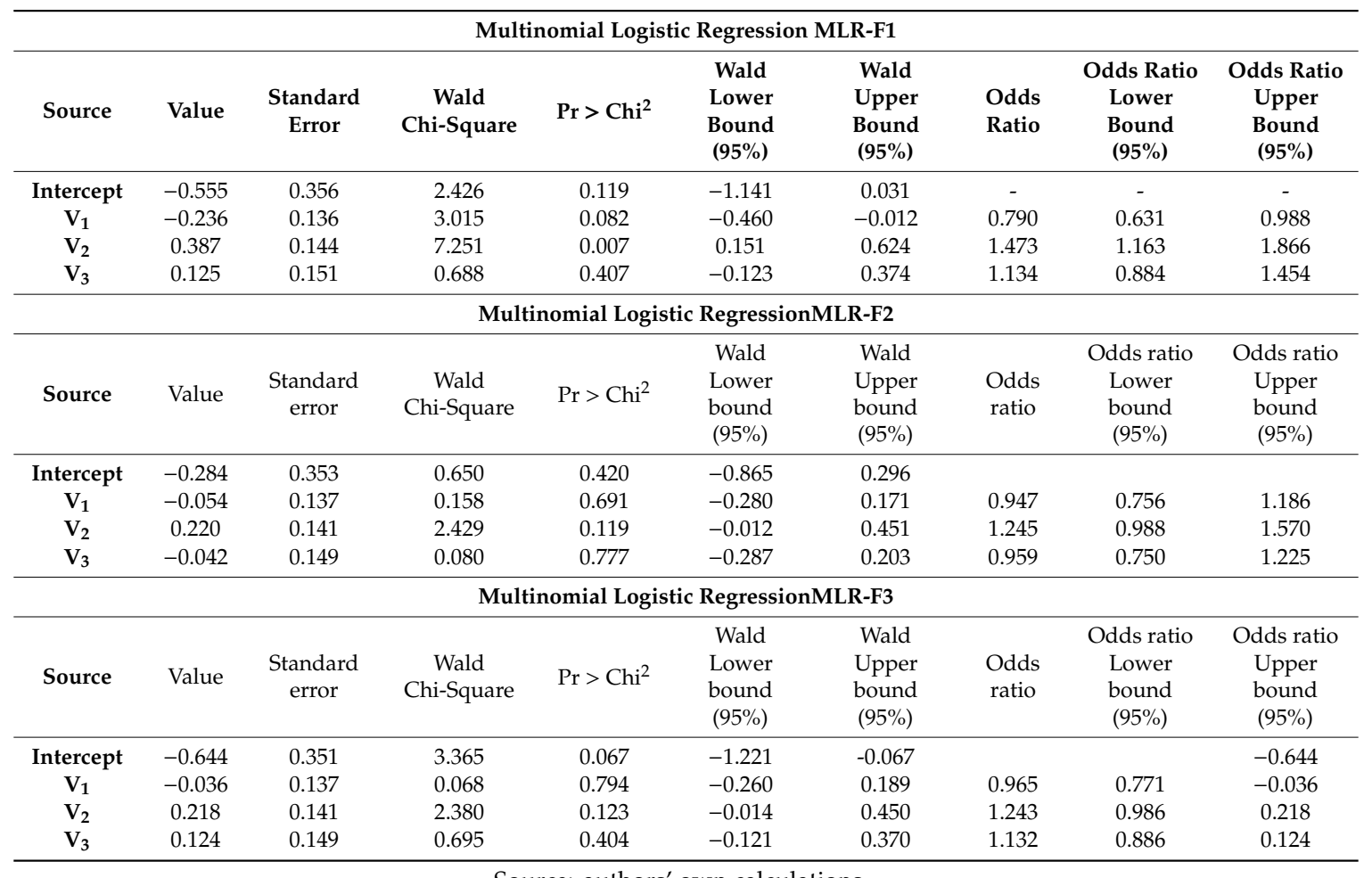

Source: authors' own calculations.

Parameter interpretation provides the following model equations:

$$
\begin{gathered}
\text { MLR - F1:Log }\left(\frac{\mathrm{P}(\text { Response variable }=5)}{\mathrm{P}(\text { Response variable }=1)}\right)=-0.555-0.236 v_{1}+0.387 v_{2}+0.125 v_{3} \\
\text { MLR - F2:Log }\left(\frac{\mathrm{P}(\text { Response variable }=5)}{\mathrm{P}(\text { Response variable }=1)}\right)=-0.284-0.054 v_{1}+0.22 v_{2}-0.042 v_{3} \\
\text { MLR - F3:Log }\left(\frac{\mathrm{P}(\text { Response variable }=5)}{\mathrm{P}(\text { Response variable }=1)}\right)=-0.644-0.036 v_{1}+0.18 v_{2}+0.124 v_{3}
\end{gathered}
$$

where $v_{1}, v_{2}, v_{3}$ represent the independent variables.

Universities are able to put their mark on sustainable development via a significant series of on-campus activities with a positive impact on the environment (such as recycling or limiting water, paper and electricity consumption) and society (such as reducing bureaucracy and supporting healthy living and working environments). The involvement of students in sustainable practices on campuses 
contributes to their attachment to the campus, deepens their desire to participate in campus initiatives and generates faith in the ability of each to make a significant change through their own behavior [60]. However, our study reveals that students' perception of on-campus activities dedicated to sustainable development has a negative impact on all types of analyzed sustainable behavior. One can easily notice that for one unit change in the variable $v_{1}$, the log ratio of the two probabilities, will be decreased by $0.236(p<0.005)$ in the case of Environmental Protection Actions, $0.054(p<0.005)$ in the case of Actions of Involvement in Community Life, and $0.036(p<0.005)$ in the case of Selective Recycling/Collection Actions. Therefore, our study shows that, in the case of business and economics students, for one unit change in their perception of Campus activities dedicated to sustainable development, students are more unlikely to adopt a sustainable development behavior. Although important steps have been taken particularly for selective recycling and water consumption reduction, these findings support the idea that the sustainable development campus activities (at least in the case of our sample) are yet to be developed. For instance, even though, garbage bins for selective collection have been installed at BUES in the hallways of the campus, this initiative was unfortunately not endorsed by a communication campaign to promote responsible behavior among students. Moreover, students may refuse to adopt an appropriate behavior due to major issues that Romania is facing in terms of coherent strategies for waste management such as a negative mentality or lack of legal consequences for non-compliance with rules. Our results are consistent with Popescu et al., who highlight poor students' involvement in on-campus activities and a lack of awareness, regardless of constant efforts from Romanian universities to hold events, conferences, symposia and conduct research projects related to sustainability [59]. However, our findings are not in agreement with Dagiliute et al., who argue that students' involvement in on-campus sustainability initiatives is significantly related to the information they have about the environment [61]. Our results suggest that the sustainability of a university is closely linked to its ability to provide the necessary infrastructure for separate waste collection, water and electricity savings. These results are not fully consistent with Dagiliute et al., who claim that recycling does not play a very important role in the case of students [61].

Moreover, even though an important series of activities have been completely digitalized within the university, these actions are not necessarily perceived by students as significant steps towards sustainable development. In addition, the feelings that some on-campus actions and events dedicated to sustainable development are, to some extent, rather compulsory than optional could significantly alter students' perception of their involvement in sustainable development behavior. Thus, the results lead to the impression that universities need to put more emphasis on voluntary involvement of students in on-campus sustainable development actions and events.

Even though, on-campus operations and students' contribution to extracurricular activities are essential to influence perception of sustainability [62], any form of constrain may lead to opposite effects.

Similarly, the collective action of students in collaboration with several stakeholders in facilitating sustainability initiatives on campuses is very important [63]. For example, Canada operates The Sustainability Youth Coalition, one of the most important non-profit organizations concerned with environmental issues and social justice [64]. Additionally, we should not overlook the movement of students from US universities against the use of fossil fuels [65]. These are only a few actions and activities that could provide a relevant benchmark for on-campus programs to promote sustainable development.

Going a step further, our analysis shows that the involvement of teaching staff in promoting sustainable behavior causes a positive impact on student behavior. According to our analysis, for one unit change in the variable $v_{2}$, the log ratio of the two probabilities, will be increased by $0.387(p<0.005)$ in the case of Environmental Protection Actions, $0.220(p<0.005)$ in the case of Actions of Involvement in Community Life, respectively $0.180(p<0.005)$ in the case of Selective Recycling/Collection Actions. Consequently, the results reveal that professors' involvement could significantly improve students' environmental protection behavior. Moreover, these results are in line with previous studies that focus on this topic. Krizek et al. [66] explained that for the successful implementation of sustainable 
initiatives on campuses, institutions can start by focusing on small-scale initiatives such as raising awareness of unsustainable human actions, recycling campaigns, courses focused on sustainability and the gradual transition to integrating sustainability into the whole system. Therefore, a simple lecture of a professor bringing to the students the problem of saving trees by limiting the excessive use of paper can be seen as a first step in raising awareness. Following the same line of thought, our findings are consistent with Avila et al. who put stress on the idea that the involvement of the entire academic community is detrimental in overcoming sustainability barriers in universities while emphasizing the need for an increased awareness from both staff and students [67]. According to some authors [5,68], the purpose of ESD is to change people's behavior towards sustainable development, and determining who can do this is of major importance. A significant distinction should be made here between mental adoption and acceptance of the importance of concepts and their effective implementation. This involves changing lifestyles and practices and does not simply end with listening to a lecture of a professor. MacDiarmid et al. showed that when we talk about the daily impact of the actions of each of us, three patterns can be identified: the tendency to minimize the role of personal habits in the global context of socio-ecological problems; serious lack of knowledge about the effects of our consumption on the environment and resistance to changing socially established consumption habits [69].

Previous studies reveal that the attitude and behavior of students towards activities specific to sustainable development tend to fluctuate [70,71], while there is a long way from attitudes to actions [71]. For example, students in economics and business studies who took part in a study conducted in Australia [72] tended to be reluctant to change their personal lifestyle since they believed that sustainable development issues (such as pollution, climate change, protection of endangered species etc.) were beyond their control and, therefore, not their personal responsibility. In contrast, students at the University of Plymouth, UK, were willing to change their lifestyle (changing shopping habits and transportation, recycling, saving water and energy etc.), although they were not familiar with the specific concepts of sustainable development [73]. In this context, our results reveal that students' perception of the extent to which curricula encompass sustainability issues has a positive impact on environmental protection actions $(0.125, p<0.005)$ and selective recycling/collection actions $(0.124, p<0.005)$ while it has a slight negative effect on involvement in community life $(-0.042, p<0.005)$. These results emphasize the need to implement sustainability issues in the curricula of economic and business faculties as a prerequisite for rethinking studies and business models in general [32]. Since sustainable development issues are involved in all social facets, there is no doubt that this kind of topic can easily find its place in any curricula. In this context, Dagiliute et al. claim that, in terms of concern and responsibility for the environment, curricula could have a significant impact on students which could be extended to their environmental behavior [61]. Going further, Ceulemans and De Prins identify two generic methods for introducing sustainability into the curricula. According to a horizontal methodology, based on a systemic and holistic approach, sustainability issues are introduced as topics to be addressed in existing curricula while the vertical approach requires distinct sustainability university courses [74]. In this sense, Stubbs and Cocklin claim that the best method is to clearly integrate specific issues of sustainability into basic courses and to avoid a merely marginal inclusion [75]. Simply put, in the case of economic higher education, sustainability topics will be addressed superficially if it is only embedded in existing courses (such as strategic management or corporate finance) [76]. In addition, students seem to hope for independent disciplines on sustainability. Thus, according to Yuan and Zuo, $75.3 \%$ of Chinese students [77], and, as Novo-Corti et al. [17] claim, $64.8 \%$ of Romanian students concur with this idea. However, this topic is far from being closed. Ramos et al. detect a series of significant challenges in including ESD into curricula and emphasize that these challenges sometimes lead to a fragmentation of knowledge [78]. Other significant impediments addressed in the literature are: teaching staff tend to perceive sustainability topics as compulsory but not relevant to curricula; lack of faculty knowledge and skills to integrate sustainability issues; absence of incentives or individual priority; limited institutional support; agglomerated curricula; limited commitment from external bodies and stakeholders [79]. Moreover, Cebrian et al. emphasize that the idea of integrating sustainability issues into most courses is 
a major challenge, which is difficult to overcome, resulting from the mismatch between ESD pedagogy and academics' views on teaching sustainability [79]. Additionally, teaching conceptual aspects of sustainability brings with it a challenge- this process requires a shift from a teacher-centered approach to a student-centered approach [80]. In effect, in terms of sustainable development topics integration, several trends were detected: (1) the inclusion of concepts in one or several existing courses [81]; (2) the addition of a dedicated course [82]; (3) the insertion of ESD principles in regular courses while adapting to the particularities of each course [81,83]; (4) the inclusion of sustainable development as a distinct potential specialty within a faculty [83]; (5) the introduction of sustainable development as a bachelor's or postgraduate program [84]. Moreover, an interdisciplinary approach is needed to stimulate interaction and interdependence between disciplines and, consequently, between people [85]. Integrating sustainability topics into curricula entails multidisciplinary cooperation, interdisciplinary guidance from different departments and faculties [86]. Stephens et al. designate transdisciplinary case studies as a successful way to integrate ESD concepts and principles into the curricula [87]. Addressing the issue of introducing an e-learning course on sustainability, Vann et al. concluded that it should have a content that encompasses aspects of environmental ethics, ecology and environmental economics [88].

However, the effectiveness of any curricula change initiative is based on the willingness of the teaching staff to change [89]. According to Eckel and Kezar, the following considerations must be taken into account: understanding the process of change; understanding why change is needed and the effective implementation of change [90]. To come to a full circle, in a study focused on business and economic students, Novo-Corti et al. reveal that the majority of students was in favor of implementing sustainability issues in curricula as an effective method to raise awareness and develop sustainable development behavior among students [17].

\section{Conclusions}

Arguably, education is one of the main drivers of sustainable development since it features the ability to transform values and behaviors, to build scientific and technical skills and to develop the proper social conduct and economic environment. However, the extensive literature review and the empirical results of our case study highlight that there is an urgent need for more coherence in shaping education to better address sustainability issues in order to effectively inspire students' behavior. Previous evidence reveals that, despite their potential to shape minds and practice, sustainability initiatives (such as training programs to promote ESD principles, on-campus initiatives or curricula development) tend to engage minority groups, failing to reach the core of all university staff, students and stakeholders, or put a significant mark on organizational culture. Moreover, as previous findings and our own results claim, even though they have a high level of awareness, students might not have the means or the willingness to act in accordance. In this context, our study aimed to estimate the extent to which various ESD initiatives are perceived by students and, consequently how these perceptions put their mark on students' sustainable behavior. In its essence, our analysis supports the idea that an increasing share of sustainable development topics combined with teaching staff involvement in raising awareness of sustainability issues are crucial to developing students' sustainable behavior. Since it provides a metric for students' sustainable behavior, the present study offers a suitable framework for decision-makers to assess the effectiveness of various instruments that universities apply according to the principles of ESD.

The on-campus activities, actions, events and programs may create a false perception that collective action is more important rather than individual action, while personal and direct interactions of teaching staff may lead to the impression that each seemingly tiny gesture of each one is important for sustainable development. Therefore, our study confirms that teaching staff personal and professional skills could be effective tools for shaping students' sustainable behavior.

Universities may have their own sets of environmental approaches and students may acquire different levels of knowledge, attitude and practice towards sustainable consumption. Similarly, the perceptible real results are contingent not only on the sustainability performance of the university, 
but also on the individual and collective actions. Since it provides a relevant case study on how ESD principles could shape students' behavior, our analysis supports the claim that universities need to undergo institutional changes, with significant changes in policies and practices, to foster their sustainable development. In this context, universities need to move from the current tactic of taking strategies in a partial and fragmentary way, adopting a proactive approach, reviewing the current mode of operation and generating mentalities to ensure the achievement of sustainable development goals.

To sum up, in this particular case study, our findings claim that, in spite of consistent efforts to implement the ESD principles, BUES still has to face urgent needs for better integration of ESD in curricula, research projects and day-to-day on-campus initiatives. In practice, BUES has to thoroughly address all facets of ESD, starting with theoretical concepts and continuing with on-campus initiatives and the power of the example set by teaching staff. In line with our findings, we recommend that the university addresses more effective sustainable development topics, at the theoretical level (a deeper integration of ESD in the curricula), but also from a practical perspective (on-campus initiatives that involve students, teaching staff, NGOs and companies). Incentives for faculty willing to engage in projects aimed at raising awareness among students should also be considered, since our study reveals that teaching staff involvement is crucial in modeling students' behaviors. We are aware that implementing ESD principles is not an easy task; however, a coherent strategy that involves targeted actions could lead to significant changes to students' perceptions and sustainable behavior. Moreover, a worldwide view on sustainable initiatives taken by a significant number of universities could provide valuable lessons such as: (1) applying an environmental management system [23]; (2) promoting environmental protection actions (e.g., planting trees [46], use of stainless steel water bottles to replace disposable bottles [91], reduce water consumption [44], etc.) or (3) funding sustainability projects [92]. In this context, the effective transfer of knowledge based on previous initiatives could be extended to a more global level and could provide a benchmark for future actions.

The research features, nonetheless, limitations and additional investigation is needed for such a complex topic. Despite the large size, the structure of the sample restricted to subjects from a single university could narrow down the present survey. Nevertheless, this study provides a framework for further research that is expected to deliver a more in depth and accurate outlook. In this context, future research could further investigate the barriers that hinder the change of knowledge into sustainable behavior.

Author Contributions: Conceptualization, L.B., G.L.Ș.-O., S.D. and G.I.P.; methodology, L.B., G.L.Ș.-O., S.D. and G.I.P.; validation, L.B., G.L.S.-O., S.D. and G.I.P.; formal analysis, L.B., G.L.S.-O., S.D. and G.I.P.; investigation, L.B., G.L.Ș.-O., S.D. and G.I.P.; resources, L.B., G.L.Ș.-O., S.D. and G.I.P.; data curation, L.B., G.L.Ș.-O., S.D. and G.I.P.; Writing-Original draft preparation, L.B., G.L.S,-O., S.D. and G.I.P.; Writing-Review and editing, L.B., G.L.S.-O., S.D. and G.I.P.; visualization, L.B., G.L.S.-O., S.D. and G.I.P. All authors have read and agreed to the published version of the manuscript.

Funding: This research received no external funding.

Acknowledgments: Part of this research has been conducted within project "Increasing the competitiveness of the national economy through retention and return strategies for young graduates of tertiary education in Romania".

Conflicts of Interest: The authors declare no conflict of interest.

\section{References}

1. Bastianoni, S.; Coscieme, L.; Caro, D.; Marchettini, N.; Pulselli, F.M. The needs of sustainability: The overarching contribution of systems approach. Ecol. Indic. 2019, 100, 69-73. [CrossRef]

2. Shiel, C.; Leal Filho, W.; do Paço, A.; Brandli, L. Evaluating the engagement of universities in capacity building for sustainable development in local communities. Eval. Program Plan. 2016, 54, 123-134. [CrossRef] [PubMed]

3. Unpacking Sustainable Development Goal 4: Education 2030. Guide-UNESCO Digital Library. Available online: https://unesdoc.unesco.org/ark:/48223/pf0000246300 (accessed on 12 August 2020).

4. Wals, A.E.J. Sustainability in higher education in the context of the UN DESD: A review of learning and institutionalization processes. J. Clean. Prod. 2014, 62, 8-15. [CrossRef] 
5. Wiek, A.; Withycombe, L.; Redman, C.L. Key competencies in sustainability: A reference framework for academic program development. Sustain. Sci. 2011, 6, 203-218. [CrossRef]

6. Ivanova, D.; Stadler, K.; Steen-Olsen, K.; Wood, R.; Vita, G.; Tukker, A.; Hertwich, E.G. Environmental Impact Assessment of Household Consumption. J. Ind. Ecol. 2016, 20, 526-536. [CrossRef]

7. FAO. Food Wastage Footprint: Impacts on Natural Resources: Summary Report; FAO: Rome, Italy, 2013; ISBN 978-92-5-107752-8.

8. United Nations Environment Programme. Consuming Differently, Consuming Sustainably: Behavioural Insights for Policymaking; UNEP: Paris, France, 2017; ISBN 978-92-807-3610-6.

9. Mahat, H.; Hashim, M.; Nayan, N.; Saleh, Y.; Haron, S.M.S. Sustainable Consumption Practices of Students through Practice-Oriented Approach of Education for Sustainable Development. Int. J. Acad. Res. Bus. Soc. Sci. 2017, 7, 703-720. [CrossRef]

10. Geng, D.; Liu, J.; Zhu, Q. Motivating sustainable consumption among Chinese adolescents: An empirical examination. J. Clean. Prod. 2017, 141, 315-322. [CrossRef]

11. Vantamay, N. Investigation and recommendations on the promotion of sustainable consumption behavior among young consumers in Thailand. Kasetsart J. Soc. Sci. 2018, 39, 51-58. [CrossRef]

12. Joshi, Y.; Rahman, Z. Investigating the determinants of consumers' sustainable purchase behaviour. Sustain. Prod. Consum. 2017, 10, 110-120. [CrossRef]

13. Tan, B.-C.; Lau, T.-C. Examining sustainable consumption patterns of young consumers: Is there a cause for concern? J. Int. Soc. Res. 2009, 2, 9.

14. Borges, J.C.; Ferreira, T.C.; Borges de Oliveira, M.S.; Macini, N.; Caldana, A.C.F. Hidden curriculum in student organizations: Learning, practice, socialization and responsible management in a business school. Int. J. Manag. Educ. 2017, 15, 153-161. [CrossRef]

15. Leal Filho, W.; Shiel, C.; Paço, A.; Mifsud, M.; Ávila, L.V.; Brandli, L.L.; Molthan-Hill, P.; Pace, P.; Azeiteiro, U.M.; Vargas, V.R.; et al. Sustainable Development Goals and sustainability teaching at universities: Falling behind or getting ahead of the pack? J. Clean. Prod. 2019, 232, 285-294. [CrossRef]

16. Piroșcă, G.I.; Șerban-Oprescu, G.L.; Badea, L.; Dedu, S. Education for Sustainable Development-An Evaluation of Students' Perceptions within the Bucharest University of Economic Studies. Amfiteatru Econ. 2020, 22, 346-361. [CrossRef]

17. Novo-Corti, I.; Badea, L.; Tirca, D.M.; Aceleanu, M.I. A pilot study on education for sustainable development in the Romanian economic higher education. Int. J. Sustain. High. Educ. 2018, 19, 817-838. [CrossRef]

18. Nolan, C. Shaping the Education of Tomorrow: 2012 Report on the UN Decade of Education for Sustainable Development, Abridged; UNESCO: Paris, France, 2012; ISBN 978-92-3-001076-8.

19. Fukukawa, K.; Spicer, D.; Burrows, S.A.; Fairbrass, J. Sustainable Change: Education for Sustainable Development in the Business School. J. Corp. Citizsh. 2013, 49, 71-99. [CrossRef]

20. United Nations Environment Programme. Greening Universities Toolkit. Transforming Universities into Green and Sustainable Campuses; UNEP: Paris, France, 2013; ISBN 978-92-807-3345-7.

21. Leal Filho, W. Sustainability and University Life. Int. J. Sustain. High. Educ. 2000, 1. [CrossRef]

22. Weber, L.E.; Duderstadt, J.J. Global Sustainability and the Responsibilities of Universities; Glion Colloquium Series No. 8; Economica: London, UK; Paris, France; Geneva, Switzerland, 2012.

23. Barros, M.V.; Puglieri, F.N.; Tesser, D.P.; Kuczynski, O.; Piekarski, C.M. Sustainability at a Brazilian university: Developing environmentally sustainable practices and a life cycle assessment case study. Int. J. Sustain. High. Educ. 2020, 21, 841-859. [CrossRef]

24. Ahamad, N.R.; Ariffin, M. Assessment of knowledge, attitude and practice towards sustainable consumption among university students in Selangor, Malaysia. Sustain. Prod. Consum. 2018, 16, 88-98. [CrossRef]

25. Moh, Y.C.; Abd Manaf, L. Overview of household solid waste recycling policy status and challenges in Malaysia. Resour. Conserv. Recycl. 2014, 82, 50-61. [CrossRef]

26. Prestin, A.; Pearce, K.E. We care a lot: Formative research for a social marketing campaign to promote school-based recycling. Resour. Conserv. Recycl. 2010, 54, 1017-1026. [CrossRef]

27. Ahmad, J.; Noor, S.M.; Ismail, N. Investigating Students' Environmental Knowledge, Attitude, Practice and Communication. Asian Soc. Sci. 2015, 11, p284. [CrossRef]

28. Barber, N.; Taylor, D.; Strick, S. Environmental Knowledge and Attitudes: Influencing the Purchase Decisions of Wine Consumers. Int. CHRIE Conf-Refereed Track. 2009. Available online: https://scholarworks.umass. edu/cgi/viewcontent.cgi?article=1010\&context=refereed (accessed on 15 August 2020). 
29. Parkes, C.; Buono, A.F.; Howaidy, G. The Principles for Responsible Management Education (PRME): The first decade-What has been achieved? The next decade-Responsible Management Education's challenge for the Sustainable Development Goals (SDGs). Int. J. Manag. Educ. 2017, 15, 61-65. [CrossRef]

30. Christie, B.A.; Miller, K.K.; Cooke, R.; White, J.G. Environmental sustainability in higher education: What do academics think? Environ. Educ. Res. 2015, 21, 655-686. [CrossRef]

31. Sibbel, A. Pathways towards sustainability through higher education. Int. J. Sustain. High. Educ. 2009, 10, 68-82. [CrossRef]

32. Figueiró, P.S.; Raufflet, E. Sustainability in higher education: A systematic review with focus on management education. J. Clean. Prod. 2015, 106, 22-33. [CrossRef]

33. Barth, M.; Godemann, J.; Rieckmann, M.; Stoltenberg, U. Developing Key Competencies for Sustainable Development in Higher Education; Social Science Research Network: Rochester, NY, USA, 2007.

34. Wakkee, I.; van der Sijde, P.; Vaupell, C.; Ghuman, K. The university's role in sustainable development: Activating entrepreneurial scholars as agents of change. Technol. Forecast. Soc. Chang. 2019, 141, 195-205. [CrossRef]

35. Blewitt, J. Higher education for a sustainable world. Educ. Train. 2010, 52, 477-488. [CrossRef]

36. Trencher, G.; Yarime, M.; McCormick, K.B.; Doll, C.N.H.; Kraines, S.B. Beyond the third mission: Exploring the emerging university function of co-creation for sustainability. Sci. Public Policy 2014, 41, 151-179. [CrossRef]

37. Brunstein, J.; King, J. Organizing reflection to address collective dilemmas: Engaging students and professors with sustainable development in higher education. J. Clean. Prod. 2018, 203, 153-163. [CrossRef]

38. Boland, J.A. Orientations to civic engagement: Insights into the sustainability of a challenging pedagogy. Stud. High. Educ. 2014, 39, 180-195. [CrossRef]

39. McNall, S.G. What's the matter with American democracy? Responding by embracing civic engagement and sustainability. In Social Responsibility and Sustainability: Multidisciplinary Perspectives Through Service Learning; Stylus Publishing: Sterling, VA, USA, 2011; pp. 61-77.

40. DeBerg, C.L. Building bridges and social capital through service learning: A blueprint model. In Social Responsibility and Sustainability: Multidisciplinary Perspectives Through Service Learning; Stylus Publishing: Sterling, VA, USA, 2011; pp. 165-186.

41. DeLaet, D.L. A Pedagogy of Civic Engagement for the Undergraduate Political Science Classroom. J. Polit. Sci. Educ. 2016, 12, 72-84. [CrossRef]

42. Barros, M.V.; da Silva, B.P.A.; Piekarski, C.M.; da Luz, L.M.; Yoshino, R.T.; Tesser, D.P. Carbon footprint of transportation habits in a Brazilian university. Environ. Qual. Manag. 2018, 28, 139-148. [CrossRef]

43. Jain, S.; Aggarwal, P.; Sharma, N.; Sharma, P. Fostering sustainability through education, research and practice: A case study of TERI University. J. Clean. Prod. 2013, 61, 20-24. [CrossRef]

44. Marinho, M.; do Socorro Gonçalves, M.; Kiperstok, A. Water conservation as a tool to support sustainable practices in a Brazilian public university. J. Clean. Prod. 2014, 62, 98-106. [CrossRef]

45. Geng, Y.; Liu, K.; Xue, B.; Fujita, T. Creating a "green university" in China: A case of Shenyang University. J. Clean. Prod. 2013, 61, 13-19. [CrossRef]

46. Wong, N.H.; Kardinal Jusuf, S.; Aung La Win, A.; Kyaw Thu, H.; Syatia Negara, T.; Xuchao, W. Environmental study of the impact of greenery in an institutional campus in the tropics. Build. Environ. 2007, 42, 2949-2970. [CrossRef]

47. Peña, F.J.A.; Jorge, M.L.; de Los Reyes, M.J.M. Analysing the incorporation of sustainability themes into the university curricula: A case study of a Spanish public university. Int. J. Sustain. Dev. World Ecol. 2018, 25, 642-654. [CrossRef]

48. Núñez, G.G. Engaging Scholarship With Communities. J. Hisp. High. Educ. 2014, 13, 92-115. [CrossRef]

49. Filho, W.L. About the Role of Universities and Their Contribution to Sustainable Development. High. Educ. Policy 2011, 24, 427-438. [CrossRef]

50. Klaniecki, K.; Wuropulos, K.; Hager, C.P. Behaviour Change for Sustainable Development. In Encyclopedia of Sustainability in Higher Education; Leal Filho, W., Ed.; Springer International Publishing: Cham, Switzerland, 2018; pp. 1-10. ISBN 978-3-319-63951-2. 
51. United Nations Development Programme. Behavioural Insights at the United Nations-Achieving Agenda 2030. 2016. Available online: https://www.undp.org/content/undp/en/home/librarypage/ development-impact/behavioural-insights-at-the-united-nations--achieving-agenda-203.html (accessed on 15 August 2020).

52. Kalamas Hedden, M.; Worthy, R.; Akins, E.; Slinger-Friedman, V.; Paul, R.C. Teaching Sustainability Using an Active Learning Constructivist Approach: Discipline-Specific Case Studies in Higher Education. Sustainability 2017, 9, 1320. [CrossRef]

53. Shephard, K. Higher education for sustainability: Seeking affective learning outcomes. Int. J. Sustain. High. Educ. 2008, 9, 87-98. [CrossRef]

54. Kolb, A.Y.; Kolb, D.A. Learning Styles and Learning Spaces: Enhancing Experiential Learning in Higher Education. Acad. Manag. Learn. Educ. 2005, 4, 193-212. [CrossRef]

55. Banos-Gonzalez, I.; Martínez-Fernández, J.; Esteve-Selma, M.-Á.; Esteve-Guirao, P. Sensitivity Analysis in Socio-Ecological Models as a Tool in Environmental Policy for Sustainability. Sustainability 2018, 10, 2928. [CrossRef]

56. Chandler, J.D.; Teckchandani, A. Using Social Constructivist Pedagogy to Implement Liberal Learning in Business Education. Decis. Sci. J. Innov. Educ. 2015, 13, 327-348. [CrossRef]

57. Menon, S.; Suresh, M. Synergizing education, research, campus operations, and community engagements towards sustainability in higher education: A literature review. Int. J. Sustain. High. Educ. 2020, 21, 1015-1051. [CrossRef]

58. Strategia Națională Pentru Dezvoltarea Durabilă a României 2030; Paideia: Bucharest, Romania, 2018; ISBN 978-606-748-261-4. Available online: http://dezvoltaredurabila.gov.ro/web/wp-content/uploads/2018/ 12/Strategia-na\%C8\%9Bional\%C4\%83-pentru-dezvoltarea-durabil\%C4\%83-a-Rom\%C3\%A2niei-2030.pdf (accessed on 15 August 2020).

59. Popescu, F.; Edu, T.; Negricea, I.C.; Zaharia, R.; Zaharia, R.M. How Do Students Assess the Sustainability of Their University? A Comparison between Dutch and Romanian Students from Business Schools. Amfiteatru Econ. 2020, 22, 411-431. [CrossRef]

60. Krasny, M.E.; Delia, J. Natural area stewardship as part of campus sustainability. J. Clean. Prod. 2015, 106, 87-96. [CrossRef]

61. Dagiliūtè, R.; Liobikienè, G.; Minelgaitè, A. Sustainability at universities: Students' perceptions from Green and Non-Green universities. J. Clean. Prod. 2018, 181, 473-482. [CrossRef]

62. Winter, J.; Cotton, D. Making the hidden curriculum visible: Sustainability literacy in higher education. Environ. Educ. Res. 2012, 18, 783-796. [CrossRef]

63. Murray, J. Student-led action for sustainability in higher education: A literature review. Int. J. Sustain. High. Educ. 2018, 19, 1095-1110. [CrossRef]

64. Mitchell, R.C. Sustaining change on a Canadian campus: Preparing Brock University for a sustainability audit. Int. J. Sustain. High. Educ. 2011, 12, 7-21. [CrossRef]

65. Grady-Benson, J.; Sarathy, B. Fossil fuel divestment in US higher education: Student-led organising for climate justice. Local Environ. 2016, 21, 661-681. [CrossRef]

66. Krizek, K.J.; Newport, D.; White, J.; Townsend, A.R. Higher education's sustainability imperative: How to practically respond? Int. J. Sustain. High. Educ. 2012, 13, 19-33. [CrossRef]

67. Ávila, L.V.; Leal Filho, W.; Brandli, L.; Macgregor, C.J.; Molthan-Hill, P.; Özuyar, P.G.; Moreira, R.M. Barriers to innovation and sustainability at universities around the world. J. Clean. Prod. 2017, 164, 1268-1278. [CrossRef]

68. Adomßent, M.; Fischer, D.; Godemann, J.; Herzig, C.; Otte, I.; Rieckmann, M.; Timm, J. Emerging areas in research on higher education for sustainable development-Management education, sustainable consumption and perspectives from Central and Eastern Europe. J. Clean. Prod. 2014, 62, 1-7. [CrossRef]

69. Macdiarmid, J.I.; Douglas, F.; Campbell, J. Eating like there's no tomorrow: Public awareness of the environmental impact of food and reluctance to eat less meat as part of a sustainable diet. Appetite 2016, 96, 487-493. [CrossRef]

70. Kyridis, A.; Mavrikaki, E.; Tsakiridou, H.; Daikopoulos, J.; Zigouri, H. An analysis of attitudes of pedagogical students towards environmental education in Greece. Int. J. Sustain. High. Educ. 2005, 6, 54-64. [CrossRef]

71. Heyl, M.; Moyano Díaz, E.; Cifuentes, L. Environmental attitudes and behaviors of college students: A case study conducted at a chilean university. Revista Latinoamericana Psicología 2013, 45, 487-500. [CrossRef] 
72. Eagle, L.; Low, D.; Case, P.; Vandommele, L. Attitudes of undergraduate business students toward sustainability issues. Int. J. Sustain. High. Educ. 2015, 16, 650-668. [CrossRef]

73. Kagawa, F. Dissonance in students' perceptions of sustainable development and sustainability: Implications for curriculum change. Int. J. Sustain. High. Educ. 2007, 8, 317-338. [CrossRef]

74. Ceulemans, K.; De Prins, M. Teacher's manual and method for SD integration in curricula. J. Clean. Prod. 2010, 18, 645-651. [CrossRef]

75. Stubbs, W.; Cocklin, C. Teaching sustainability to business students: Shifting mindsets. Int. J. Sustain. High. Educ. 2008, 9, 206-221. [CrossRef]

76. Benn, S.; Dunphy, D. Action Research as an Approach to Integrating Sustainability Into MBA Programs: An Exploratory Study. J. Manag. Educ. 2009, 33, 276-295. [CrossRef]

77. Yuan, X.; Zuo, J. A critical assessment of the Higher Education For Sustainable Development from students' perspectives-A Chinese study. J. Clean. Prod. 2013, 48, 108-115. [CrossRef]

78. Ramos, T.B.; Caeiro, S.; van Hoof, B.; Lozano, R.; Huisingh, D.; Ceulemans, K. Experiences from the implementation of sustainable development in higher education institutions: Environmental Management for Sustainable Universities. J. Clean. Prod. 2015, 106, 3-10. [CrossRef]

79. Cebrián, G.; Grace, M.; Humphris, D. Academic staff engagement in education for sustainable development. J. Clean. Prod. 2015, 106, 79-86. [CrossRef]

80. Erskine, L.; Johnson, S.D. Effective Learning Approaches for Sustainability: A Student Perspective. J. Educ. Bus. 2012, 87, 198-205. [CrossRef]

81. Thomas, I. Sustainability in tertiary curricula: What is stopping it happening? Int. J. Sustain. High. Educ. 2004, 5, 33-47. [CrossRef]

82. Cortese, A.D. The Critical Role of Higher Education in Creating a Sustainable Future. Plan. High. Educ. 2003, $8,15-22$.

83. Kamp, L. Engineering education in sustainable development at Delft University of Technology. J. Clean. Prod. 2006, 14, 928-931. [CrossRef]

84. Lozano, F.J.; Lozano, R. Developing the curriculum for a new Bachelor's degree in Engineering for Sustainable Development. J. Clean. Prod. 2014, 64, 136-146. [CrossRef]

85. Kolb, M.; Fröhlich, L.; Schmidpeter, R. Implementing sustainability as the new normal: Responsible management education-From a private business school's perspective. Int. J. Manag. Educ. 2017, 15, $280-292$. [CrossRef]

86. Juárez-Nájera, M.; Dieleman, H.; Turpin-Marion, S. Sustainability in Mexican Higher Education: Towards a new academic and professional culture. J. Clean. Prod. 2006, 14, 1028-1038. [CrossRef]

87. Stephens, J.C.; Hernandez, M.E.; Román, M.; Graham, A.C.; Scholz, R.W. Higher education as a change agent for sustainability in different cultures and contexts. Int. J. Sustain. High. Educ. 2008, 9, 317-338. [CrossRef]

88. Vann, J.; Pacheco, P.; Motloch, J. Cross-cultural education for sustainability: Development of an introduction to sustainability course. J. Clean. Prod. 2006, 14, 900-905. [CrossRef]

89. Harpe, B.D.L.; Thomas, I. Curriculum Change in Universities: Conditions that Facilitate Education for Sustainable Development. J. Educ. Sustain. Dev. 2009, 3, 75-85. [CrossRef]

90. Eckel, P.D.; Kezar, A. Key Strategies for Making New Institutional Sense: Ingredients to Higher Education Transformation. High. Educ. Policy 2003, 16, 39-53. [CrossRef]

91. Thongplew, N.; Kotlakome, R. Getting a drink: An experiment for enabling a sustainable practice in Thai university settings. J. Clean. Prod. 2019, 218, 294-303. [CrossRef]

92. Evans, J.; Jones, R.; Karvonen, A.; Millard, L.; Wendler, J. Living labs and co-production: University campuses as platforms for sustainability science. Curr. Opin. Environ. Sustain. 2015, 16, 1-6. [CrossRef]

(C) 2020 by the authors. Licensee MDPI, Basel, Switzerland. This article is an open access article distributed under the terms and conditions of the Creative Commons Attribution (CC BY) license (http://creativecommons.org/licenses/by/4.0/). 